\title{
Situating Decolonization: An Indigenous Dilemma
}

\begin{abstract}
Being Indigenous and operating in an institution such as a university places us in a complex position. The premise of decolonizing history, literature, curriculum, and thought in general creates a tenuous space for Indigenous and non-Indigenous peoples to confront a shared colonial condition. What does decolonization mean for Indigenous peoples? Is decolonization an implied promise to squash the tropes of post-coloniality? Or is it a way for non-Indigenous people to create another paradigm or site for their own resistance or transgression of thinking? What are the roles of Indigenous and non-Indigenous peoples in this space of educational potential, this curriculum called decolonization? This article presents a multi-vocal reflection on these and related questions.
\end{abstract}

\section{Keywords}

Coloniality, Curriculum theory, Decolonization, Indigenous, Pacific Peoples

\section{Opening remarks}

This article is a collaboration between seven members of an Indigenous sub-group of PESA, the Philosophy of Education Society of Australasia (www.pesa.org.au); a collaboration beginning at the PESA conference in Fiji, December 2016. Its format reflects the research metaphors of wānanga (Henry \& Pene, 2001) or talanoa (Vaioleti, 2006), calling on an Indigenous notion of a collaborative meeting of minds, seeking though not demanding consensus. The wānanga metaphor is named for the whare wānanga of traditional Māori society, which was a formal institution for generating and transmitting important knowledge (Barlow, 1991). Talanoa, or talking, in the sense of village discussion, is a basic element of Samoan and Tongan life, which has become a popular approach in Aotearoa-New Zealand for researching Pacific education (Suaalii-Sauni \& Fulu-Aiolupotea, 2014).

Indigeneity, or being an Indigenous person, is dependent on location in a specific space and time, so, by definition, a range of Indigenous views cannot be homogenized or generalized. What, then, does it mean to 'decolonize' the curricula of schooling and higher education? This question is becoming urgent in Australia, Aotearoa-New Zealand, Hawai'i and the island nation-states of the South Pacific, which collectively make up the homelands of the co-authors. Decolonizing the curriculum takes a slightly different shape in each jurisdiction, according to the details and trajectory of local social history. The past and current situations of the Indigenous peoples of Australia and Aotearoa-New Zealand are similar but divergent; the peoples of the Pacific island nation-states share much in common with each other, but also retain distinct differences. Samoan, Tongan and other Pacific Peoples in Aotearoa-New Zealand or Australia are not 'Indigenous' in these larger countries, yet are often lumped into 'Indigenous' categories in school policy and practice. Hawai'i, a small part of the United States 
in the Pacific, has one of the most multi-ethnic populations in the world. Hawai'i has a diverse Indigenous education milieu, with many Indigenous families trapped in urban or rural poverty, but with robust expanding Indigenous education programmes that are sites of recovery of Indigenous Hawai'ian language and culture.

As we collectively explored the question of decolonizing education, it became clear that trying to blend together our experiences would risk continuing the colonizing practices and assumptions of traditional, Eurocentric research on Indigenous education. This lack of assimilability of our voices signals the limits of the category of 'the Indigenous' (Mika \& Stewart, 2016; Peters \& Mika, 2017). One effect of the widespread acceptance of the category of 'the Indigenous' within scholarship is to generate a reified binary of Indigenous vs. Western/European knowledge, extended to people and culture, which underlies discussions in this article.

Our aim is to explore the situation of Indigenous knowledge in the curriculum, but in so doing we relegate Western/European knowledge to the Other, homogenized and caricaturized, just as happens to Indigenous knowledge incorporated into the academic curriculum. A disclaimer is therefore necessary concerning the simplistic nature of references to Western/European knowledge below. For exploring Indigenous knowledge, it is useful to think of the contrasting characteristics of Western/European knowledge as found in universities; a strategic simplification for pedagogical purposes, outlined in the following paragraph.

The linear, fragmenting thinking that is privileged in universities has its roots in Platonic metaphysics; from there it gains momentum with (among other things) Aristotle's theory of predication, the medieval problem of universals, Leibniz's idea of a universal symbolism, as well as modern empiricism and rationalism' (Seung-hwan, 2004, p. 233). The deep and protracted influences of Western philosophy have endured, despite such apparent recent threats as post-truth, new materialism and poststructuralism. Protected to such an extent that it is almost a non-issue, the rationalism of dominant Western philosophy is so embedded that it is invisible. We can perhaps best describe it as so proximate that it cannot be seen - although its essence in fact lies somewhere behind the eyes, guiding how the world may/may not be determined.

The next section is presented as a metaphorical talanoa or wānanga: a sequence of curated responses from our various perspectives, starting with some general Indigenous challenges to curriculum. Anchoring the section are three accounts of located experience: of Indigenous Hawai'ian education; of a Samoan scholar, and finally a Tongan scholar, the latter two being situated in Aotearoa-New Zealand. The last part of the section reconsiders decolonization in relation to the Indigenous/Western binary in philosophy. The final section of the article presents some provisional suggestions and openings for further exploration. 


\section{Talanoa - Wānanga - Contributions to the discussion}

[Author 1 name] from Indigenous Australia. There is a strong aspiration for institutions in many countries, including those represented by the authors of this article, to 'decolonize' curriculum and for the curriculum to be inclusive of Indigenous content. Regardless of such motivations to achieve this ambition, issues arise due to the complexities surrounding colonial states - both in the physical and metaphysical senses. Ever since the renewed interest in Indigenous ways of knowing the following question has been raised: 'What happens, or what do we need to consider, when Indigenous Knowledge is brought into relation with the disciplines in the academy?' (Nakata, 2008, p. 183). Although this question refers to Indigenous ways of knowing in research, it also applies to decolonizing or Indigenizing curriculum. What is decolonization? Decolonization must be understood within the context of coloniality in order for it to be de-contaminated, which therefore raises the question of whether curriculum can possibly be decolonized, because it is colonial in-and-of-itself?

[Author 2 name] from Aotearoa. How realistic is the claim that the school curriculum should change to enable better success for Indigenous student populations? Schooling has been integral to colonizing the Indigenous populations of settler or immigrant nation-states around the globe. The experiences of Māori in schools, as with other Indigenous peoples, has been a multi-generational history of alienation, trauma and systemic under-achievement, acting as a significant cause of Māori impoverishment at the level of the population (Carpenter, Jesson, Roberts, \& Stephenson, 2008).

Teachers play a key role as knowledge workers: a role it is important not to lose sight of amongst the myriad expectations on a teacher in the daily life of a school. The currency and capital of schooling takes the form of knowledge (Bourdieu, 1991), and the curriculum organizes this knowledge (Pinar, 2012). In other words, curriculum is the educational technology that systematizes the knowledge of school capital. This concept of technology uses Heidegger's (1977) definitive delineation of technology's essence as an 'enframing' of some aspect of nature as a standing-reserve; a resource for humanity's use. Similarly, 'curriculum' is a human invention, or technology, that enframes knowledge for use in the schooling practices of pedagogy and assessment.

Curriculum is therefore a fundamental part of Western-style education, from which comes schooling. Naturally teachers are mainly concerned with 'what' they will teach; few have opportunities to reflect on 'how' and 'why' curriculum questions. Such questions about the workings of curriculum are thus central in curriculum research, applying across the curriculum and to all education sectors. Critical studies of curriculum reveal the inherently racist nature of the school curriculum (Castenall \& Pinar, 1993). Therefore, efforts to make compulsory schooling more successful for the Indigenous population must be centrally concerned with the school curriculum.

But if critical curriculum theorists are correct, colonizing effects are built into the central concept of the school curriculum (Doll, 1993; Young, 1996). If so, then the concept of a 
'decolonizing curriculum' is a contradiction in terms, because how can the curriculum change to become its opposite, namely a decolonizing technology? This difficult question is often overlooked in claims for critical, multicultural or anti-racist education (May \& Sleeter, 2010; McLaren \& Torres, 1999). Teachers are encouraged to add items of Indigenous knowledge or language to the existing curriculum, in the ostensible belief that this makes schooling more relevant for Indigenous students, and so increases their chances of success (Ministry of Education, 2011). The claim that items of Indigenous knowledge can be 'added' to teaching programmes is therefore problematic: the above argument suggests any attempt to include Indigenous knowledge in the curriculum is bound to distort Indigenous knowledge. The result is often cultural caricature: inert knowledge, shorn of its original contexts, webs of meaning, and corresponding fields of practice. Such incremental changes may make the curriculum more appealing but ought not be blithely elided with the paradoxical notion of a decolonizing curriculum.

[Author 3 and Author 4 names] from Hawai'i write about indigenizing Hawai 'ian education: The existence and possibility of decolonization in educational institutions is politically complicated, but we would like to share the efforts that are underway to Ho'ohawai'i, meaning to cause, become or invigorate 'Hawai'i, within educational institutions.

We consider ourselves blessed to have taught at our alma mater, a school 'established by the last direct descendant of the Hawaiian monarchy (Princess Bernice Pauahi Bishop) for the education and upbringing of Native Hawaiians' (Doe v. Kamehameha Schools, 2006, p. 1). The school has an admissions policy that allows for all of the students who attend to be Kanaka 'Öiwi (Aboriginal people of Hawai'i). The current CEO of the Kamehameha Schools, Jack Wong, recently stated, 'she [Princess Pauahi] wanted to use education to restore her people...That is our charge’ (O‘Connell, 2018).

To carve a path toward restoration, the school leadership has released a strategic plan known as Kühanauna (Kamehameha Schools, 2015). Inspired by Princess Bernice Pauahi Bishop's original intentions, Kühanauna is being used to direct the complete re-working of the educational institution's policies and practices. Guided by Kühanauna, in 2016 the school released E Ola! Learner Outcomes at Kamehameha. (Kamehameha Schools, 2016). The first learner outcome listed is: 'Ike Kupuna - ancestral experiences, insights, perspectives, knowledge, and practices.

Kanaka 'Ōiwi scholar, Kanalu Young (1998), expands upon the work of Greg Dening which uses the Beach and the Island as a metaphor for the interaction between Native and haole (foreign) knowledge systems. Dening proposes that while the Island is the innermost workings of Native knowledge systems, the Beach is where haole ideas come ashore and the differing epistemologies meet. Young points out that before anyone can get to the Beach it is the Papa (reef) which greets them. Young then augments Dening's metaphor by detailing a topography of the Island, describing the Awāwa, which contains the '[T]he most valued and revered knowledge, inaccessible to but a few' (Young, 1998, p. 17). The Awāwa relies on the Papa for protection. 
In order for the Kamehameha Schools to achieve the first learner outcome, 'Ike Kupuna, educators are compelled to spend time in the Awāwa, immersing ourselves in the fertile environment of Native knowing. In addition to a visceral understanding of Aloha 'Āina, Hawaiian philosophy, 'ike kupuna requires in-depth knowledge of the Hawaiian language and the ability to apply such knowledge to one's particular 'oihana (occupation)' (Young, 1998, p. 19).

Our 'oihana, as Kanaka educators in a 21 st-century educational institution, positions us on Papa. Fixing ourselves on Papa allows us to engage with haole ideas while rooted in a Native foundation. We recognize that Kanaka 'Ōiwi educators standing on Papa leave our bodies vulnerable to the crashing of waves. The Awāwa reminds us of our kuleana (responsibility/privilege) to stand in this space and also reassures us, ' $[\mathrm{H}] \mathrm{e}$ po'i na kai uli, kai ko'o, 'a'ohe hina pūko'a (though the sea be deep and rough, the coral rock remains standing)' (Puku'i, 1983, loc. 4061).

The Awāwa that we visit regularly is also known as mo'olelo, which can be defined as a 'continuous or connected narrative; a history, a tradition' (Andrews, 1865, p. 395). As an oral culture, the Kanaka 'Ōiwi store much knowledge in mo'olelo. The mo'olelo that we regularly access were recorded in 'ōlelo Hawai'i prior to American occupation (Sai, 2011). We do this in order to ensure that our foundation is based in an 'ano Hawai'i (Hawaiian temperament/style). "Ano also means image, as in "the reflection of a face in a mountain pool" (Young, 1998, p. xi), and identity, as in 'the character of a person' (Andrews, 1865, p. 57).

[I]ndigenous teachers carry the burden ... to act as a 'bridge' between Indigenous and non-Indigenous communities; to be role models for Indigenous students and to take responsibility for the implementation of Indigenous education policies and initiatives at the school level. (Santoro, 2011, p. 72)

The effort to Ho'ohawai' $i$ is based on the idea that life thrives in the Awāwa and that a culture placed in a museum gathers dust and becomes outdated and eventually extinct. Ho'ohawai' $i$ involves filtering and transforming what approaches the Papa, bringing knowledge and ideas consistent with the 'ano Hawai' $i$ to the Beach and translating this knowledge to supplement the Awāwa if deemed worthy. Grounded in the 'ano Hawai' $i$, we endeavour to see the reflection of our kupuna (ancestors) in the eyes of our students. It is our sincere hope that the education we provide to our children is more Hawai' $i$ than the education that we received in our own schooling. With hope-filled hearts, we also firmly believe that the education which will be provided in the tomorrows to come will be even more Hawai'i still.

[Author 5 name] from Tonga in Aotearoa-New Zealand writes about being Tongan as coming from a position of strength: As a Tongan/Pasifika doctoral scholar and a practitioner working within the context of Tongan Early Childhood Education (ECE), I experience first-hand the ongoing struggles of finding a 'space' with meaning that includes acknowledgement of the Tongan epistemic and ontological world against a background of European theory and practice. 
My place of strength situates my being and thinking within our Tongan language and culture. My position situates my talanoa (stories/dialogue) on a Tongan fala (mat), a position of strength where decolonization is at its most valuable when sharing with others. Pacific peoples have been over-researched from a deficit perspective and have experienced the disempowering effects of research in New Zealand (Vaioleti, 2006). Educational researchers need to build from the strengths of Pacific peoples so the results can be useful and beneficial.

Our parents migrated to New Zealand hoping for better educational opportunities for their children. The learning journey continues with contradicting sets of values even after migrating to Aotearoa and those contradictions are not well understood and documented (Helu-Thaman, 2002). The contradictions continue, in pursuing doctoral research with a desire to highlight contradictory implications between Tongan teachers' experiences and official requirements of education policies. When in academic surrounds my thoughts often veer to an uncomfortable 'space' because prevailing worldviews assume the universal, while our Pacific peoples are rendered both invisible and over-represented in educational research and statistics.

Decolonization from Tongan Indigenous thought embraces the sacred 'space' known as the vā that exist outside the 'common' construct of educational research. Our worldviews and ontologies are placed on a collective orientation made up of tauhi vā or reciprocal relationships with our people, connected to the fonua (land), genealogies and the entire cosmos. What remains consistent with this idea of vā is that knowledge/worldview is holistic, and it lives through the process and daily experiences. Vā thinking acknowledges the differing worldviews and embraces post-structuralist ideas. Decolonization remains a challenge for Indigenous scholars who are within the university because of the general assumption of educators and researchers that there is a common truth. Tongan place is rooted in the fonua where land, relationships, peoples, seas, skies and the entire cosmos is connected.

In a Tongan cultural context, the interplay of mind, body and soul, individual and collective, spatiality and temporality provide complex notions of how one sees the world. This complexity indicates some of the struggles of attempting to translate our 'differences' in thinking and being within Western discourses. Explaining this can be a difficult and hesitant task. The premise of decolonizing history, literature, curriculum, and thought in general, is difficult because of this 'difference' between Tongan and European thinking. The quest for decolonization includes developing a widespread respect and understanding of cultural values that underpin a 'minority' culture, such as Tongan culture within an Anglophone academic environment.

Decolonization must start from a place that does not involve a deficit way of thinking; a place that does not blame, a place of differing worldviews, and a place that seeks transformation and change for the better. Decolonizing from a position of strength has the capacity to empower other non-Indigenous cultures to experiment for themselves; to find that there are other, multiple ways of knowing that exist other than the prevailing one. The construct of a linear and fragmented worldview needs to give way to a holistic, relational fluidity and flexibility of being. Such a sentiment is closer to the Indigenous way of thinking and being. It will be a difficult task to decentre the dominant culture, to let other ways of knowing into the space that 
exists within current education system.

The kind of modernist thinking which underpins the competitive environment is created by the belief in universal truths and reality, which makes no sense to those who have a different sense of realities. For some people like Tupua Tamasese and colleagues (2005), the concerns are for the priority of Indigenous thought. The importance of the 'pursuit of Indigenous Pacific knowledge is that it survives - and survives because it gives us meaning and belonging' (p. 5). Decolonization must start from a place of strength; a place that is open to other ways of knowing and being. Only there can we find meaning and belonging within our own sense of identity.

[Author 6 name] from Samoa in Aotearoa-New Zealand, writes about traversing Oceania in Aotearoa: As a Samoan lecturer in Pasifika early childhood teacher education in Aotearoa I have grown increasingly skeptical of cultural constructs that are readily accepted in normative education practice, particularly concepts that are presented as universal to all Pacific peoples, based upon humanistic ideals and deontological ethics. A recent story by Pacific scholar Kabini Sanga raised concerns about how cultural knowledge must also be critiqued within relevant onto-epistemological structures. This would suggest that even Pacific Indigenous worldviews are to be open to critique and rigour, and that opening new relations to cultural knowledge formations contests the very nature of knowledge as fixed or static. These are tensions and questions that I continue to navigate when confronting my personal convictions to decolonize education. How does a Pacific researcher attempt to decolonize education, keeping in movement possibilities for emergent cultural concept creation, and how can Pacific worldviews offer alternative ways of thinking about relational ethics within the world?

Tongan scholar Epeli Hau'ofa wrote extensively about the lasting effects of colonizing regimes on anthropological research in the Pacific, particularly the geographical naming and so-called division of the Pacific Ocean (Melanesia, Micronesia and Polynesia). Hau'ofa contested such geographical divisions of Pacific spheres, and the notion of the Pacific as consisting of many small islands.

But if we look at the myths, legends and oral traditions, and the cosmologies of the peoples of Oceania, it will become evident that they did not conceive of their world in such microscopic proportions. Their universe comprised not only land surfaces, but the surrounding ocean as far as they could traverse (Hau'ofa, 1993, p. 7).

The act of critique by Pacific Indigenous thinking opens a cosmic paradigm that affects the spatio-temporality of being, between human and Ocean. This way of conceptualizing belonging to Oceania (not only Islands) is significant to me personally, as I operate to decolonize education and Pacific research from a location other than my ancestral lands of Samoa. Born in Aotearoa, having spent most of my life living in Aotearoa, I call this my home. I have grown an affinity to specific places; my maunga (mountain), my awa (river), my shared connection with whenua (land/placenta) and lasting relationships with tangata whenua (Māori). 
Through Pacific research, I am coming to understand the collective histories Māori share with Oceania and Pacific peoples.

My hope for the ongoing process of 'decolonizing' research, education and ethics is grounded on the idea that cultural knowledge constructs are ontologically situated with and through the various forms of Indigenous wisdoms, rather than ideals of universality too often accepted as normal in education. Another example of engaging such wisdom(s) to address the problem of bio-ethics in the Pacific come from his highness Tui Atua Tupua Tamasese Ta'isi Efi (former head of state of Samoa and Samoan knowledge custodian) who has theorized the concept of tofa sa'ili, which is the ongoing human pursuit for knowledge (Tui Atua, 2009). Tofa sa'ili in Samoan research calls into question harmony between human and non-human life and the capacity to think beyond human comprehension (human spirit). This example of wisdom presents an unfolding (past, present, future) as all life forms, human and non-human, are cosmically connected. Decolonizing as an embodied and embedded practice of wisdom(s) is in part about coming to know self in relation to others (past and present, cosmos, land, seas, and skies). Calling upon wisdom(s) from a Samoan-Pasifika worldview and in the spirit of Oceania as a decolonizing force, I express this poem:

\section{Time}

Sitting on the edge of the small cliff looking down The dark brown and green waters a few meters out The glistening mud, still wet, soft...

Why do you move away from me when I visit you today?

It's not in your time that I move...

The strong salty air, wrapping around my cold cheeks and ears - my nose turning red

Whispering winds that hold stories of Oceanic travels, tides shifting, Popping sounds of crabs and the millions of holes that spot the mud.

Why do you move away from me when I visit you today?

It's not in your time that I move...

Crevices trailing behind the water's edge, the veins carved into earth

Earth, mud, life, birth, waters bleed and break

When Pacific lands rose up out of the waters,

And like the wind, people carried Oceanic stories

Why do you move away from me when I visit you today?

It's not in your time that I move...

[Author 7 name] from Aotearoa. From an early age, Indigenous peoples are trained in the ways of rational thought. If they attend universities, this schooling in perception likely reaches its zenith, with students dissuaded from speaking emotionally or obscurely. Thus, any discussion about de/colonization references the bitter, inescapable fact that colonization starts at the level of invisibility with a forced rational perception (Mika, 2017). With that in mind, our pessimism deepens, because any form of decolonization based on the use of one's native tongue, 
incorporating native stories, etc, within the colonizing ontology of the rational text, is merely dancing with the symptoms. Even research under the rubric of Kaupapa Māori, which is broadly described as a Māori way of doing things, often does not sufficiently question the fundamental ontological ground of the text that it purports to 'Māorify'. Such as approach assumes that the field of Western thought is somehow neutral - that our work becomes 'Māori' simply by adopting a set of categories that reflect Māori values. But the colonizing nature of that field of invisible perception immediately 'over-talks' the native tongue or 're-stories' the native narrative. In that sense, colonization in education is primarily not whatever shimmers on the surface of schools or universities, but rather of the deepest recesses. It cannot be empirically verified or taken to task through logic, though its nature is vaguely accessible through our powers of speculation.

A debate that often emerges in Indigenous scholarship is about working with the Western philosopher or theorist. This dilemma assumes the field of Western thought is somehow neutral - that our work becomes 'Indigenous' simply by adopting a set of categories that reflect Indigenous values. Those categories themselves, though, have always-already been established, through Western thinkers and others, to corral thought so that it will always be partly Western in its nature. More speculatively, from a Māori metaphysics, those decisive Western thinkers are still materially evident in that field of thought. The question of whether we should overtly refer to the Western philosopher in our work, then, is one that comes too late.

\section{So, where to from here?}

The metaphysics of logic, clarity and linearity that underpin colonization, while imposed and inescapable for the Indigenous scholar, can serve productive ends for Indigenous education and research - its form of 'saving power' (Heidegger, 1977) that immediately rebounds from the repugnance of its history. As Indigenous scholars, before we can call on the vulnerability of metaphysical colonizing myths as a possible antidote for philosophical oppression, we must 'make even logic itself suspect [for] such a reflection to be radical' (Gordon, 2010, p.6). This is not to say that logic can be fully decolonized, but more realistically it can perhaps be destabilized. This act of 'temporary overturning' is open to the eternal dialectic of assertion/negation with origins in ancient Māori metaphysics. For example, colonization and destabilization grapple together to produce something novel which is then claimed by colonization, undermined by destabilization, and so on, ad infinitum. Identifying as far as possible how colonization works in thought and thought's representation, and addressing the devices of colonization through holistic devices of our own - including those that bring words together in unusual combinations or interpret a thing in the world through a deliberately obscure lens - could be a starting point to at least identifying 'that-which-cannot-really-bedetermined': the un-entity of colonization.

Universities exist within a continued habitus of coloniality, because this is how they are formed, and they carry their colonial baggage wherever they go. Underlying the ambition to decolonize is a sense of this baggage and all its trimmings facing a possible redundancy. There 
is much at stake in the process of bringing our knowledges into this mess. However, it is easily recognized that we are already in a 'mess'. So how does curriculum fit into this? Curriculum can be a platform where we find possible distinct ways in creating voices of self-determination and self-definition. It is therefore necessary to subvert and reconfigure this platform and create spaces away from its original formation.

It is our challenge as Indigenous peoples and communities to break our silence and create and engage in new terrains of not only resistance and survival but enrichment through the centering and privileging of our own Knowings.' (Blair, 2015, p. 176)

Blair sees decolonization as a strategic discourse, yet as one of the 'bricks' in the Eurocentric wall. We need to remember where decolonization comes from and maintain a healthy suspicion about the risks that threaten memory, reconstituting an amnesia that suppresses our voice and ways of knowledge production.

Where to start? The colonial settlers need to undertake deep self-reflection in order to build relationality, and to seek immersive experiences and embodied acts to help develop 'deep listening'. This is essential to achieve a curriculum that can be possibly decolonized. In this process, we as Indigenous peoples need to lead the way, and although once again it seems like the onus is on us, we cannot forget that with resistance comes responsibility.

Cultural decolonization in the Canadian context is about at once unsettling settlers and, ironically, helping them to adapt, to better settle themselves as non-colonial persons within Indigenous spaces. (Garneau, 2013, p. 15)

For the non-Indigenous scholar of education in Australia, New Zealand or the Pacific island nations, it would be important to consider the line between interest in and appropriation of Indigenous knowledge. The link is tenuous between the non-Indigenous appetite to know more about Indigenous knowledge and culture, often of a symbolic and rarified form, and the actual realities of a life of struggle experienced by many, if not most, Indigenous school students. As Indigenous scholars, are we inviting non-Indigenous peoples to join us in a shared space called decolonization? Or is the demand for decolonization coming from the non-Indigenous side?

The approach of building relationality is an Indigenous one. The difference in this process is there is a rightful expectation on the colonial settler to immerse themselves in this dynamic, as they are the ones that hold the majority in institutions. The deal is that Indigenous peoples can lead the process so long as there is an unequivocal commitment from our non-Indigenous counterparts. This is how we start the process and we hope for it to spread in such a way that the majority 'deeply' learns the privilege of Indigenous ways of knowing. Let's wait and see (again).

\section{References}

Andrews L. (1865). A Dictionary of the Hawaiian Language. Henry M. Whitney. Honolulu, HI. 
Barlow, C. (1991). Tikanga whakaaro: key concepts in Māori culture. Oxford, UK: Oxford University Press.

Bell, A. (2014). Relating Indigenous and settler identities: beyond domination. New York, NY: Palgrave Macmillan.

Blair, N. (2015). Privileging Australian Indigenous Knowledge: Sweet Potatoes, Spiders, Waterlilys, and Brick Walls. Champaign, IL. Common Ground Publishing.

Bourdieu, P. (1991). Language and Symbolic Power. Cambridge: Polity Press.

Carpenter, V., Jesson, J., Roberts, P., \& Stephenson, M. (Eds.). (2008). Ngā kaupapa here: Connections and contradictions in education. South Melbourne, Australia: Cengage Learning.

Castenall, L. A., \& Pinar, W. (Eds.). (1993). Understanding Curriculum as Racial Text: Representations of Identity and Difference in Education. Albany NY: State University of New York Press.

Doll, W. E. (1993). A post-modern perspective on curriculum. New York \& London: Teachers College Press.

Gordon, L. (2010). Fanon on decolonizing knowledge. In A. Hoppe \& T. Nicholls (Eds.), Fanon and the decolonization of philosophy (pp. 3-18). Plymouth, England: Lexington Books.

Hau'ofa, E. (1993). A New Oceania: Rediscovering our Sea of Islands. Suva, Fiji: University of the South Pacific.

Heidegger, M. (1977). The question concerning technology andother essays. New York: Harper Torchbooks.

Henry, E., \& Pene, H. (2001). Kaupapa Māori: locating indigenous ontology, epistemology and methodology in the academy. Organization, 8(2), 234-242.

Kamehameha Schools. (2015). Kamehameha Schools Strategic Plan 2015-2020: Kühanauna - A Generation on the Rise. Retrieved from https://www.ksbe.edu/assets/Kuhanauna_KS_Strategic_Plan_2015-2020.pdf

Kamehameha Schools. (2016). E Ola! Learner Outcomes at Kamehameha. Retrieved from https://www.ksbe.edu/imua/article/sharing-e-ola-learner-outcomes-creates-acollective-understanding-of-ks-edu/

May, S., \& Sleeter, C. E. (Eds.). (2010). Critical multiculturalism: theory and praxis. New York: Routledge, 2010.

McLaren, P., \& Torres, R. (1999). Racism and Multicultural Education: Rethinking 'Race' and 'Whiteness' in Late Capitalism. In Critical Multiculturalism: Rethinking Multicultural and Antiracist Education: Falmer Press.

Mika, C., \& Stewart, G. (2016). Māori in the Kingdom of the Gaze: Subjects or critics? Educational Philosophy and Theory: Incorporating ACCESS, 48(3), 300-312. https://doi.org/10.1080/00131857.2015.1013017.

Ministry of Education. (2011). Tätaiako: Cultural competencies for teachers of Māori learners. Wellington, New Zealand: Crown copyright.

Nakata, M. (2008) Disciplining the Savages, Savaging the Disciplines. Canberra, ACT: Aboriginal Studies Press.

O‘Connell, M. (2018). New Vision for Kamehameha Schools. Honolulu Star Advertiser, July 8. Retrieved from https://www.staradvertiser.com/2018/07/08/editorial/insight/newvision-for-kamehameha-schools/

Peters, M. A., \& Mika, C. T. (2017). Aborigine, Indian, indigenous or first nations?

Educational Philosophy and Theory, 49(13), 1229-1234.

Pinar, W. (2012). What is curriculum theory? New York, NY: Routledge.

Puku'i, M. K. (1983). 'Ōlelo No'eau: Hawaiian Proverbs and Poetical Sayings. Honolulu, HI: Bishop Museum Press. 
Sai, David Keanu. (2011). Ua Mau ke Ea Sovereignty Endures: An Overview of the Political and Legal History of the Hawaiian Islands. Honolulu, HI: Pu 'a Foundation.

Santoro, Ninetta, Jo-Anne Reid, Laurie Crawford, and Lee Simpson. (2011). Teaching Indigenous children: listening to and learning from Indigenous teachers. Australian Journal of Teacher Education 36(10), 65-76.

Seung-hwan, L. (2004). A typography of Confucian discourse: Politico-philosophical reflections on Confucian discourse since modernity (J. Song \& L. Seung-hwan, Trans.). Paramus, NJ: Homa \& Sekey.

Suaalii-Sauni, T., \& Fulu-Aiolupotea, S. M. (2014). Decolonising Pacific research, building Pacific research communities and developing Pacific research tools: The case of the talanoa and the faafaletui in Samoa. Asia Pacific Viewpoint, 55(3), 331-344.

Tamasese, K., Peteru, C., Waldegrave, C., \& Bush, A. (2005). Ole Taeao Afua, the new morning: a qualitative investigation into Samoan perspectives on mental health and culturally appropriate services. Australian and New Zealand Journal of Psychiatry, 39, 300-309.

Tui Atua, T. T. T. E. (2009), Bioethics and the Samoan Indigenous reference. International Social Science Journal, 60, 115-124.

Vaioleti, T. (2006). Talanoa research methodology: a developing position on Pacific research. Waikato Journal of Education, 12, 21-34.

Young, Kanalu G. T. (1998). Rethinking the Native Hawaiian Past. New York, NY: Routledge.

Young, R. (1996). Decolonising education: the scope of educational thought. Studies in Philosophy and Education, 15, 309-322. 